\title{
TESTING OF 24 POTENTIALLY HAZARDOUS WASTES USING 6 ECOTOXICOLOGICAL TESTS
}

\section{Jörg Römbke *}

ECT Oekotoxikologie GmbH, Böttgerstr. 2-14, D-65439 Flörsheim, Germany

Article Info:
Received:
12 January 2018
Revised:
1 October 2018
Accepted:
31 October 2018
Available online:
3 December 2018
Keywords:
Test battery
Aquatic
Terrestrial
Eluates
Soil
Reference

\section{INTRODUCTION}

In the European Union, the hazard properties of wastes have to be determined following Commission Regulation (EU) $N^{\circ} 1357$ (EU 2014). However, until quite recently it was not specified how the HP 14 property ("ecotoxic": waste which presents or may present immediate or delayed risks for one or more sectors of the environment) has to be assessed, but this situation has changed (see Council Regulation (EU) 2017/997). In fact, two approaches are possible:

1. Evaluation according to the classification of chemical mixtures (Classification, Labelling and Packaging CLP approach - EC 2008).

\section{ABSTRACT}

The ecotoxicological characterization of wastes according to the European Waste (EWL) is part of their assessment as hazardous or non-hazardous. Despite inclusion in national laws no methodological details have been fixed concerning the hazproperty HP 14 ("ecotoxic").This paper intends to discuss the classification of wastes by ecotoxicological testing, using 24 representative samples of solid wastes (identified by their EWL number) with different properties. They were sampled according to standard methods, and, with one exception (galvanic sludge), ecotoxicologically tested. No chemical investigation of the samples was performed but they were characterized according to their properties in the ABANDA data base. Nearly all of these wastes were "mirror entries" in the EWL (i.e., they can be hazardous or not depending on the concentration of hazardous substances). For the ecotoxicological characterization three aquatic tests with eluates (genotoxicity, Algae, Daphnia) as well as three terrestrial tests with solid wastes (bacteria, plants, earthworms) were conducted. All investigations were performed as limit tests with three dilution steps. Algae, plants and terrestrial bacteria were the most sensitive organisms. Since no waste eluate showed any indication of genotoxicity, the genotoxicity test should be replaced by the luminescent bacteria test (ISO 11348-3). Proposals for toxicity criteria as well as hazard classifications were taken from the literature but they were modified according to own experiences. Using these concentration limits for the classification whether these wastes are ecotoxic or not, and using different versions of the hazard classification approach, 15-19 waste samples out of 23 waste samples were classified as ecotoxic (64-83\%). It is proposed to perform a plausibility check of the respective HP 14-classification. The procedure used in this contribution (i.e. sampling of the wastes, their ecotoxicological testing as well as their hazard classification) could form the basis of a standardized hazard classification approach as proposed recently in the literature. In summary, this works confirms that ecotoxicological tests are practical and sensitive in order to be used for the ecotoxicological hazard classification of very different wastes.
The hazard of a waste is calculated based on its composition, i.e. adding-up the concentrations of all chemicals with chronic aquatic toxicity (Council Reg. 2017/997 (EU 2017)). Details on the pros and cons of this approach are, for example, given by Wahlström et al. (2016). However, wastes contain many, often unknown chemicals, and even in case they are known, it is not certain that ecotoxicological data are available for them (Eurelectric 2016). In addition, no interactions between the individual waste components are considered. However, according to the recent Council Regulation in case ecotoxicological tests were performed with a respective waste their results will prevail (EU 2017).

2. Ecotoxicological testing of wastes, using standard ISO (International Organization for Standardization) methods. 
Originally, this approach was developed for the assessment of contaminated soils (see e.g. ISO 15799 (2002f) and ISO 17616 (2008b). In short, it consists of a battery of aquatic and terrestrial tests, whose results are assessed together. Recent discussions focus on the selection of the appropriate leaching method as well as on questions regarding the interpretation of the results (Wahlström et al. 2016). Recently, this approach has been (slightly modified) taken over in the Technical Report "Guidance on the use of ecotoxicity tests applied to construction products" products (CEN/TR 17105 (2017)).

Such an ecotoxicological test battery has been successfully used for different waste materials in France (Pandard et al. 2006), Germany (Römbke et al. 2009; Moser et al. 2011) and in particular in an international ring-test (Moser and Römbke 2009). One outcome of this ring-test was to use three test methods for waste eluates and three tests for solid wastes, but there was still some doubt which test methods exactly should be included in the test battery. For reasons of acceptance and data quality standardized test methods should be used (preferably, either ISO, CEN (Comité Européen de Normalisation) or DIN (Deutsches Institut für Normung)). It is also recommendable for any test battery to cover species from the three main trophic organism groups (microbes, plants and animals) in order to cover a wide range of physiological and ecological properties. Finally, the number of three test methods per compartment (aquatic/eluates and terrestrial/solid wastes) seems to be a good compromise between general coverage and practicability (i.e. the efforts in terms of time and costs are manageable).

However, a broad comparison of the toxicity of many different waste types investigated with exactly the same methods had not been done so far. Therefore, a project was funded by the German Federal Environmental Agency (UBA), whose results are summarized in this contribution. The aims of this work can be summarized as follows:

- Evaluation of the suitability (i.e. practicability, sensitivity, reliability and robustness) of six standardized test methods when used for the hazard classification of 24 waste samples which differ strongly in their physico-chemical and toxicological properties;

- Comparison of different assessment options using the whole data set from this exercise (including recommendations for a specific option);

- Comparison of the results of these tests with those tests proposed by Pandard and Römbke (2013); note that they recommend the luminescent bacteria test (ISO 11348-3 (2007)) but in this contribution a genotoxicity test was used instead of the bacterial luminescent test (see also Figure 1 and Chapter 4.2). This proposal is based on discussions in Workgroup 7 of CEN/TC 292/WG 7 "Characterization of waste - Ecotoxicological properties". It consists of an attempt to combine the two approaches for assessing the ecotoxicological hazard of wastes.
So far it is not known how many wastes would be classified as hazardous when their classification is based on ecotoxicological tests. The work presented here is intended to provide a first answer to this question by testing a high number of very different wastes in parallel.

\section{MATERIAL AND METHODS}

\subsection{Tested wastes and their properties}

In close co-operation with the German Federal Environment Agency (UBA) the wastes to be studied were identified using the following criteria:

- Not classified as hazardous;

- Economically relevant, mainly in terms of their amount; - Broad coverage of the List of Wastes (EC 2000);

- Problematic due to variable composition with potentially hazardous properties;

- Difficult to classify as ecotoxic regarding the HP 14 property.

When applying these criteria, it quickly became clear that - for different reasons - it was often difficult to get the wastes we had selected, partly because they were not available in Germany or the owners were reluctant in providing them. In Table 1, the outcome of the selection process is listed. Wastes already classified as hazardous according to one of the other 13 hazard criteria, were with one exception - not considered, since in these cases the fulfilment of the property HP 14 would not change the already existing classification as being "hazardous". It was planned to test all 24 wastes listed here, but when getting the waste classified as Code No. 110110 it was realized that it was in fact a highly condensed but still fluid galvanic sludge. Since this sample could not be tested in ecotoxicological tests, the final number of tested waste samples was 23 .

Ideally, waste samples are characterized chemically and physically. However, due to the heterogeneous composition of these materials this is a very exhaustive and expensive exercise. Therefore, the origin of these waste types was compiled from the waste owners, while information on major contaminants were taken from a database named ABANDA (organized by the German state of North-Rhine-Westphalia) (Table 1). However, this information is not specific for the individual sample tested.

\subsection{Sampling of wastes}

Collecting representative samples from heterogeneous composite wastes still poses several difficulties. Here the definitions provided by the German "Federal Working Group on Waste (LAGA)" were used, which focus on the material quality of a waste as part of its characterization (LAGA 2004). A compilation of the currently available documents and recommendations in the context of waste testing are combined in the method collection of the LAGA-Forum "waste testing" (LAGA 2012). Thus, the following procedure was used for the sampling for ecotoxicological testing of wastes (Römbke and Ketelhut 2014).

In order to minimize the risk that an analytical result is 


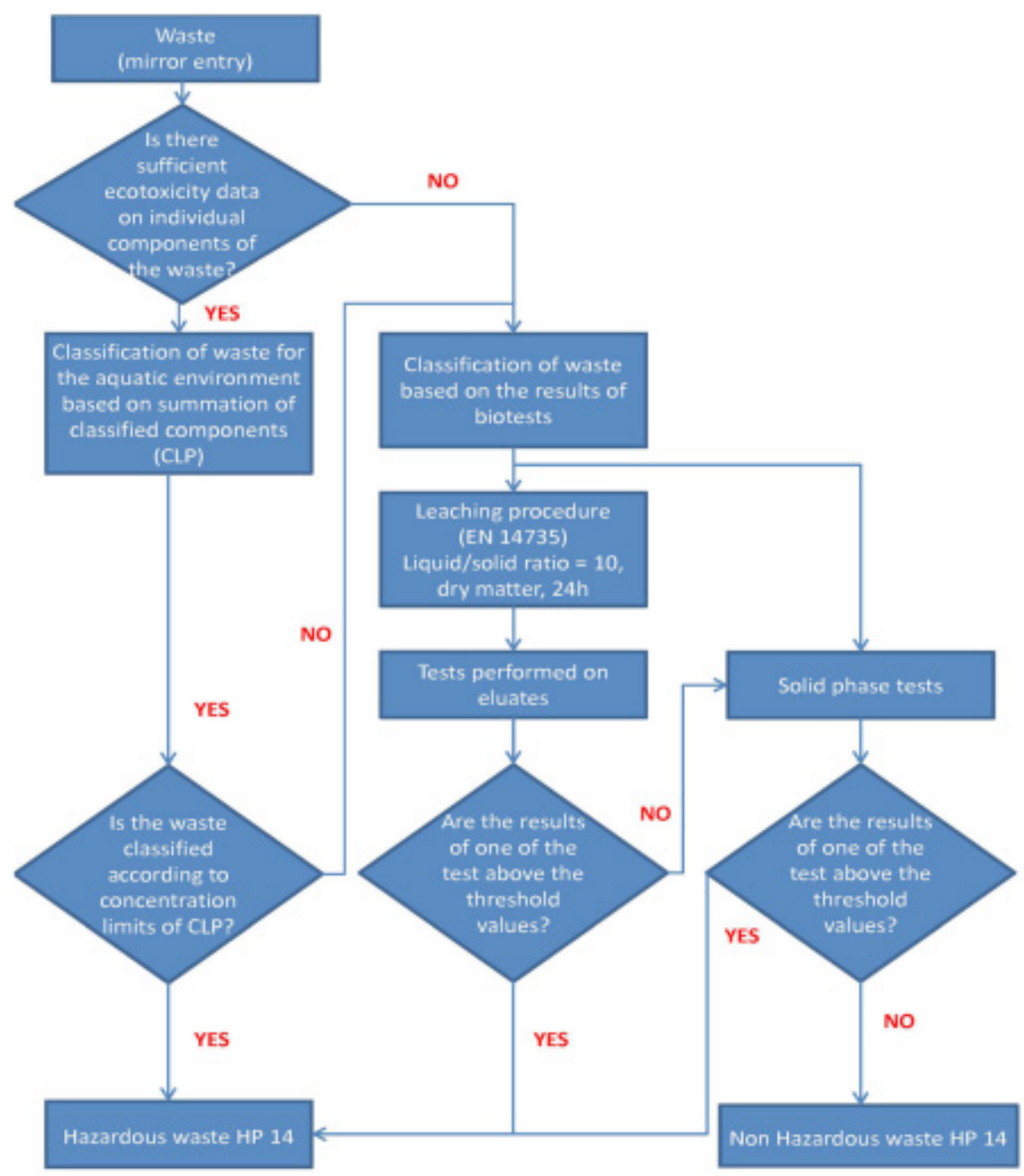

FIGURE 1: Flowchart for the assessment of the HP 14 property (Pandard and Römbke, 2013).

strongly influenced by singular particles samples should offer a tight spectrum of particle size. This could be proven by sieve analysis which is recommended to be done for any sample taken from heterogeneous waste materials:

- In a laboratory sample the mass above the 20th percentile of the sieve analysis should be represented by more than 20.000 particles.

- Any sampling should ideally be performed at random points in time across the whole transversal section of the particle mass flow falling from a conveyor belt. In case this is not possible the sampling should be performed from the heap of waste.

- When taking samples from a heap of waste, it should be secured that no phase separation did occur during the set-up of the heap.

- Independently from the size of the basic sample, at least 16 single samples have to be taken.

- The individual samples should be random samples. In other words: each particle of the basic population should have the same probability to be part of an individual sample.

- Sampling from a heap of waste could be performed using a wheel loader. The 16 samples taken should be combined to a two-dimensional flat layer providing a height of 1-1.5 dm. Samples could be randomly taken from random coordinates of this two-dimensional layer. - All individual samples should be combined to one mixed laboratory sample.

- A sample size reduction without a previous reduction in particle size is not allowed.

- The addition of preservatives (e.g. acids) for the purpose of delaying chemical and biological processes does not conform to the standard CEN 14735 (2005).

The duration of the transport of waste samples was as short as possible (i.e. less than $48 \mathrm{~h}$ ) and the samples were not stored for longer than two months (temperature: $\leq 8^{\circ} \mathrm{C}$ ).

\subsection{Test organisms and test performance}

\subsubsection{Aquatic tests}

The aquatic test methods used in this study are briefly described in Tables 2-4.

\subsubsection{Terrestrial tests}

The terrestrial test methods used in this study are briefly described in Tables 5-7. 
TABLE 1: Wastes tested, classified according to the Code of the European Waste List (EC 2000). * = waste classified as hazardous since it fulfills one of the 14 hazard criteria. One sample could not be tested (given in italics). Conc. = concentration. Note that most of these wastes could be classified as either hazardous or non-hazardous (i.e. "mirror entries"), with two absolute non-hazardous exceptions and one absolute hazardous exception. For "mirror entries", the most relevant code has been underlined according to their origin and contamination, when possible.

\begin{tabular}{|c|c|c|}
\hline Code & Waste type & Origin and Contamination \\
\hline $010505^{\star}$ & Oil containing drilling mud and wastes & Soil soaked with mineral drilling oil; probably high PAH conc. \\
\hline$\frac{060315^{\star} /}{060316}$ & Metallic oxides & $\begin{array}{l}\text { Waste from titan dioxide production; } \mathrm{pH} \text { ca. } 4 \text {; } \mathrm{Cd}, \mathrm{Cr}, \mathrm{Cu}, \mathrm{Ni}, \mathrm{Zn} \\
\text { content possible }\end{array}$ \\
\hline$\underline{080115^{\star} /}$ & Aqueous sludges containing paint or varnish & $\begin{array}{l}\text { Coating and point remnants from a car body shop, high Zn content, } \\
\text { probably low biocide conc. }\end{array}$ \\
\hline$\frac{100116^{*} /}{100117}$ & Fly ash from co-incineration & $\begin{array}{l}\text { Fine dust from electric filters in a coal plant. Very high } \mathrm{Pb}, \mathrm{Cu}, \mathrm{Zn} \\
\text { conc. }\end{array}$ \\
\hline$\frac{110109 * /}{110110}$ & Sludges and filter cakes & Waste water concentrate from a print shop (fluid galvanic sludge) \\
\hline$\frac{120116^{*} /}{120117}$ & Waste blasting material & $\begin{array}{l}\text { Waste blast dust plus paint remnants from the body of a ship; } \mathrm{Pb}, \mathrm{Th} \text {, } \\
\mathrm{Zn} \text { conc. high }\end{array}$ \\
\hline $\begin{array}{l}170106 * / \\
170107\end{array}$ & Mixtures of concrete, bricks, tiles and ceramics & Mixed construction waste. Low PAH conc. \\
\hline $\begin{array}{l}170201 / \\
170204^{*}\end{array}$ & Wood & $\begin{array}{l}\text { Old wood from construction sites; } \mathrm{Pb}+\mathrm{Zn} \text { contamination, paint } \\
\text { remnants }\end{array}$ \\
\hline $\begin{array}{l}170503 * / \\
170504\end{array}$ & Soil and stones & Soil from construction sites \\
\hline$\frac{170505^{\star} /}{170506}$ & Dredging spoil & $\begin{array}{l}\text { Dredged material from Hamburg harbor. Probably contaminated by } \\
\text { organo-tin-substances. }\end{array}$ \\
\hline$\frac{170507 * /}{170508}$ & Track ballast & Stoney material from rail tracks. High $\mathrm{Cu}, \mathrm{Pb}, \mathrm{Zn}+\mathrm{PAH}$ conc. \\
\hline $\begin{array}{l}170801 * / \\
170802\end{array}$ & Gypsum-based construction materials & $\begin{array}{l}\text { Fine gypsum material from construction waste sites, partly mixed } \\
\text { with paper remnants }\end{array}$ \\
\hline $\begin{array}{l}170903 \star / \\
170904-A\end{array}$ & $\begin{array}{l}\text { Mixed construction and demolition wastes (we got two of these } \\
\text { samples; this was identified as A) }\end{array}$ & $\begin{array}{l}\text { Mineral, metallic and woody mixture from waste containers, very } \\
\text { heterogeneous, but no contaminants. }\end{array}$ \\
\hline $\begin{array}{l}170903 * / \\
170904-B \\
\end{array}$ & $\begin{array}{l}\text { Mixed construction and demolition wastes (we got two of these } \\
\text { samples; this was identified as B) }\end{array}$ & $\begin{array}{l}\text { As sample } 1709 \text { 04-A, but higher plastic content and less insulation } \\
\text { material }\end{array}$ \\
\hline 190802 & Waste from de-sanding & $\begin{array}{l}\text { Material from waste water channels, mixed with polymer flocking } \\
\text { agent. High } \mathrm{PAH}, \mathrm{Cu}, \mathrm{Zn} \text { contamination }\end{array}$ \\
\hline $\begin{array}{l}190813^{\star} / \\
190814\end{array}$ & Sludges from other treatment of industrial waste water & Filter press sludges from a painting plant; no specific contaminants \\
\hline$\frac{191003^{*} /}{191004}$ & Fluff-light fraction and dust & $\begin{array}{l}\text { Selected light material from a reprocessing plant. High conc. of } \\
\text { various heavy metals, incl. } \mathrm{Hg}\end{array}$ \\
\hline 191205 & Glass & Origin: TV screens. High Pb conc. \\
\hline$\frac{191206^{*} /}{191207}$ & $\begin{array}{l}\text { Wood (wastes from the mechanical treatment of waste) } \\
\text { (we got three of these samples; this one did not get an addition- } \\
\text { al identifier) }\end{array}$ & Wooden ULD pallets; maybe low $\mathrm{Cr}$ conc. \\
\hline$\frac{191206^{*} /}{191207}$ & $\begin{array}{l}\text { Wood (wastes from the mechanical treatment of waste) (fur- } \\
\text { niture) (we got three of these samples; this one was identified } \\
\text { as A) }\end{array}$ & $\begin{array}{l}\text { Construction and furniture material, } 5 \text { years stored; maybe low } \mathrm{Cr} \\
\text { conc. }\end{array}$ \\
\hline$\frac{191206^{*} /}{191207}$ & $\begin{array}{l}\text { Wood (wastes from the mechanical treatment of waste) (mixed) } \\
\text { (we got three of these samples; this one was identified as B) }\end{array}$ & $\begin{array}{l}\text { Community storage pile, age unknown } \\
\text { maybe low } \mathrm{Cr} \text { conc. }\end{array}$ \\
\hline$\frac{191211^{*} /}{191212}$ & $\begin{array}{l}\text { Other wastes (including mixtures of materials) from mechanical } \\
\text { treatment of wastes }\end{array}$ & $\begin{array}{l}\text { Mainly styrol-based plastic particles, few organic or metal parts; } \\
\text { extremely heterogenous; high conc. of heavy metals possible, mainly } \\
\text { Zn }\end{array}$ \\
\hline$\frac{191301 * /}{191302}$ & Solid wastes from soil remediation & $\begin{array}{l}\text { Soil material strongly contaminated by } \mathrm{PAH} \text { and mineral oil, but also } \\
\mathrm{Pb}, \mathrm{Zn}, \mathrm{Cu}, \mathrm{Cr} \text { and } \mathrm{PCB}\end{array}$ \\
\hline$\frac{200137 * /}{200138}$ & Wood & Wooden bulk trash, maybe low $\mathrm{Cr}$ conc. \\
\hline
\end{tabular}

\subsection{Control and mixture media in the tests}

Ecotoxicity testing of waste requires the use of a dilution medium which does not affect the response of the test organisms and does as little as possible interact with the sample. The same medium must be used for both the control and the dilution series (see also CEN 14735 (2005)).
Depending on the ecological requirements of the test species and the requirements listed in the ISO-standard different control and mixture media were used.

\subsubsection{Aquatic tests}

The aquatic organisms were tested with eluates, which were prepared according to CEN 12457-2 (2003), i.e. with a 
TABLE 2: Umu genotoxicity test (ISO standard 13829 (ISO 2000).

\begin{tabular}{|c|c|}
\hline Test system: & Salmonella choleraesius subsp. choleraesius (formerly: Salmonella typhimurium) TA 1535/pSK1002 \\
\hline Test duration: & $4 \mathrm{~h}$ \\
\hline Test parameter: & Comparison of the induction of the umuC-gene in comparison to spontaneous activations in the negative control \\
\hline Threshold value: & Induction rate $(\mathrm{IR}) \geq 1.5$ \\
\hline Test medium: & Tryptone, glucose, ampicillin (TGA) medium \\
\hline pH (control): & $7.0 \pm 0.2$ \\
\hline Temperature: & $37 \pm 1^{\circ} \mathrm{C}$ \\
\hline Light conditions: & Darkness \\
\hline Test vessels: & 96 well microtitration plates (optical clear) \\
\hline Volume / vessel: & $380 \mu \mathrm{l}$ \\
\hline Validity criteria: & Minimum growth in the negative control = $140 \mathrm{FNU}$ (formazine nephelometric units) \\
\hline $\begin{array}{l}\text { Reference chemical / Positive } \\
\text { control: }\end{array}$ & 4-Nitro-quinolin-N-Oxid, 2-Aminoanthracen \\
\hline
\end{tabular}

TABLE 3: Green algae growth test (ISO standard 8692 (ISO 2004a).

\begin{tabular}{|c|c|}
\hline Test system: & Pseudokirchneriella subcapitata \\
\hline Test duration: & $72 \mathrm{~h}$ (permanently shaking) \\
\hline Test parameter: & Growth in comparison to control \\
\hline Threshold value: & $25 \%$ \\
\hline Test medium: & Mixture of four nutrient stock solutions in water \\
\hline pH (control): & $8.1 \pm 0.2$ \\
\hline Temperature: & $21-24^{\circ} \mathrm{C}$ (fluctuations $<2^{\circ} \mathrm{C}$ ) \\
\hline Light conditions: & $60-120 \mu \mathrm{E}^{\star} \mathrm{m}^{-2} \mathrm{~s}^{-1}$ permanent light \\
\hline Test vessels: & 300 ml Erlenmeyer flasks (microtiter plates) \\
\hline Volume / vessel: & $100 \mathrm{ml}$ water \\
\hline Validity criteria: & $\begin{array}{l}\text { Increase of cell density in the controls by a factor of } 67 \text { after } 72 \mathrm{~h} \text { (i.e. growth rate } \geq 1.41 \text { ); increase of } \mathrm{pH} \leq 1.5 \text { during } \\
\text { the test; coefficient of variation in the control } \leq 5 \%\end{array}$ \\
\hline $\begin{array}{l}\text { Reference chemical / Positive } \\
\text { control: }\end{array}$ & Potassium dichromate or 3,5-Dichlorophenol? \\
\hline
\end{tabular}

TABLE 4: Daphnia magna test (ISO standard 6341 (ISO 2012).

\begin{tabular}{|c|c|}
\hline Test system: & 5 juvenile Daphnia magna (age 2-26 h) per replicate \\
\hline Test duration: & $24 \mathrm{~h}$ \\
\hline Test parameter: & Immobilization of the water flea \\
\hline Threshold value: & $20 \%$ \\
\hline Test medium: & Reconstituted water according to OECD 203 (1992) \\
\hline pH (control): & $7.5-8.0$ \\
\hline Temperature: & $20 \pm 2^{\circ} \mathrm{C}$ \\
\hline Light conditions: & Permanently dark \\
\hline Test vessels: & $50 \mathrm{~mL}$ vessels without lid \\
\hline Volume / vessel: & $20 \mathrm{~mL}$ eluate/water mixture or water (controls) \\
\hline Validity criteria: & Mortality in the control $\leq 10 \%$ \\
\hline $\begin{array}{l}\text { Reference chemical / Positive } \\
\text { control: }\end{array}$ & Potassium dichromate \\
\hline
\end{tabular}

solid/liquid dilution ratio of 1:10. The elution medium was distilled water and an end-over-end tumbler was used. After $24 \mathrm{~h}$, the eluate was centrifuged for $20 \mathrm{~min}$ at $17000 \mathrm{x}$ $\mathrm{g}$ and finally it was filtered $(<0.45 \mu \mathrm{m})$. In the Luminescent Bacteria test the control culture medium is TGA, consisting of tryptone, glucose and ampicillin. In the Algae test the control growth medium is a mixture of four nutrient stock solutions in water, which are defined as follows: No. 1: five macro-nutrients, No. 2: Fe-EDTA; No. 3: seven trace elements; No. 4: $\mathrm{NaHCO}_{3}$; all of them in specific concentrations. In the Daphnia test the test medium is reconstituted water, which is a mixture of four nutrient salts in deionized water (Calcium chloride, magnesium sulfate, sodium bicarbonate, and potassium chloride) in specific ratios. 
TABLE 5: Arthrobacter globiformis test (ISO standard 18187 (ISO 2016)).

\begin{tabular}{|c|c|}
\hline Test system: & Arthrobacter globiformis (freeze-dried) \\
\hline Test duration: & $<1 \mathrm{~d}$ (Incubation time $2 \mathrm{~h}$ ) \\
\hline Test parameter: & Dehydrogenase activity \\
\hline Threshold value: & $30 \%$ \\
\hline Test medium: & Mixtures of Quartz sand and waste material \\
\hline pH (control): & $5.0-7.5$ \\
\hline Moisture: & $20 \%$ (up to $33 \%$ possible) \\
\hline Temperature: & $30 \pm 1^{\circ} \mathrm{C}$ \\
\hline Light conditions: & Dark \\
\hline Test vessels: & 24-well microplate \\
\hline Volume / vessel: & $0.6 \mathrm{~g}$ weighed in a micro-well \\
\hline Validity criteria: & $\begin{array}{l}\text { Relative fluorescence increases by a factor }>5 \text { during a measuring time of } 0 \text { to } 60 \text { min. Coefficient of variation for the } \\
\text { average slope of relative fluorescence in the negative control replicates is less than } 15 \%\end{array}$ \\
\hline $\begin{array}{l}\text { Reference chemical / Positive } \\
\text { control: }\end{array}$ & Benzalkonium chloride (BAC) $(600 \mathrm{mg} / \mathrm{kg}$ ) causes effects between $30 \%$ and $80 \%$ \\
\hline
\end{tabular}

TABLE 6: Higher plant test (ISO standard 11269-2 (ISO 2004b)).

\begin{tabular}{|c|c|}
\hline Test system: & Brassica napus (turnip), 10 seeds per replicate (4 replicates per dilution step) \\
\hline Test duration: & $14-21 \mathrm{~d}$ after $50 \%$ of seeds in the control emerged \\
\hline Test parameter: & $\begin{array}{l}\text { Determination of the emergence rate within the first week. At the end of the test determination of the fresh weight } \\
\text { and visible damages }\end{array}$ \\
\hline Threshold value: & $30 \%$ \\
\hline Test medium: & Mixtures of LUFA 2.3 standard soil and waste material \\
\hline pH (control): & Not specified \\
\hline Moisture: & On demand \\
\hline Temperature: & $25 \pm 10^{\circ} \mathrm{C}$ \\
\hline Light conditions: & Light/dark cycle: ca. 16/8 h; Light intensity: $13000 \pm 5000 \mathrm{~lx}$ \\
\hline Test vessels: & Plastic pots, diameter about $10 \mathrm{~cm}$ \\
\hline Volume / vessel: & $900 \mathrm{~g}$ soil / soil-waste mixture (fresh weight) \\
\hline Validity criteria: & Emergence rate in the control: $>70 \%$ \\
\hline $\begin{array}{l}\text { Reference chemical / Positive } \\
\text { control: }\end{array}$ & EC50 (boric acid): 80 - 330 mg/kg soil (dry weight) for the endpoint shoot weight (see also Becker et al. 2011) \\
\hline
\end{tabular}

TABLE 7: Earthworm avoidance test (ISO standard 17512-1 (ISO 2008a)).

\begin{tabular}{|c|c|}
\hline Test system: & 10 adult Eisenia fetida (biomass $250-600$ mg/worm) per test vessel; 5 replicates per dilution step \\
\hline Test duration: & $48 \mathrm{~h}$ \\
\hline Test parameter: & Avoidance behavior determined at the end of the test \\
\hline Threshold value: & $80 \%$ \\
\hline Test medium: & Mixtures of OECD Artificial Soil and waste material \\
\hline pH (control): & 5.5-6.5 \\
\hline Moisture: & $40-60 \%$ of the WHCmax \\
\hline Temperature: & $18-22^{\circ} \mathrm{C}$ \\
\hline Light conditions: & 16 h light (400-800 Lux), 8 h dark \\
\hline Test vessels: & Bellaplast vessels, $11 \times 15.5 \times 6 \mathrm{~cm}$ \\
\hline Volume / vessel: & $500 \mathrm{~g}$ soil / soil-waste mixture \\
\hline Validity criteria: & $\begin{array}{l}\text { Mortality in the control } \leq 10 \% \text { per vessel; distribution with same soil on both sides: } 50 \pm 10 \% \text { (see also Hund-Rinke and } \\
\text { Wiechering 2001) }\end{array}$ \\
\hline $\begin{array}{l}\text { Reference chemical / Positive } \\
\text { control: }\end{array}$ & Boric acid at $750 \mathrm{mg} / \mathrm{kg}$ soil (dry weight) should cause avoidance behavior \\
\hline
\end{tabular}




\subsubsection{Terrestrial tests}

In the Bacteria-test the control was quartz sand (with $50 \%$ to $75 \%$ of sand with particle size between $0,063 \mathrm{~mm}$ and $2 \mathrm{~mm}$ ). The natural standard soil LUFA Soil 2.3 was used in the Plant test, which fulfilled the following conditions: organic carbon content $\leq 1.5 \%$, pH between 5.0 and 7.5 , and the fine fraction should comprise less than $20 \%$ of the soil dry weight. In the Earthworm Test the control soil was OECD Artificial Soil, consisting of $10 \%$ dry mass Sphagnum peat finely ground and with no visible plant remains (particle size $<1 \mathrm{~mm}$ ), $20 \%$ of Kaolinite clay containing not less than $30 \%$ kaolinite and $69 \%$ industrial quartz sand (dominant fine sand with more than $50 \%$ to $75 \%$ of particle size $0.0563 \mathrm{~mm}$ to $0.2 \mathrm{~mm}$ ).

\subsection{Test design}

All tests were performed following an Extended Limit Test design, i.e. with three dilutions of the tested waste eluate or solid waste. These concentrations differed between the two compartments as follows:

- Aquatic tests: control (0\%), D8 (= 12.5\%), D4 (= 25.0\%), D2 (= 50.0\%).

- Terrestrial tests: control (0\%), D16 (= 6.25\%), D8 (= $12.5 \%)$, D4 (= 25.0\%).

Note that due to technical reasons (number of wells on a micro-well plate) the dilution steps differed from the rest in the genotoxicity tests: Control (0\%), D12 (= 8.3\%), D6 (= $16.7 \%)$, D3 (= 33.3.0\%), D 1,5 (66.6\%).

These dilutions were chosen in order to include the general limit concentration LID (= Lowest Ineffective Dilution) of 4 and 8 for aquatic and terrestrial tests, respectively. This approach is widely used in Germany for the assessment of contaminated land but has rarely been used in other countries (e.g. ISO 17616 (2008). The reason for the different dilutions in the aquatic and terrestrial tests is caused by the lower availability of contaminants in the solid test media.

\subsection{Threshold (reference) values as effect criteria for the individual tests}

Depending on the biological variability of each test system the effect criterion (i.e. which difference between a tested mixture and the respective control is considered as an effect) differs too (Tables 2-8). Originally, these criteria have been proposed for the evaluation of contaminated soil, partly in the test standard itself (e.g. ISO 17512-1 (2008a), partly in regulatory documents (e.g. Moser 2008) or, just as an example, in other international standards (e.g. ISO 17616 (ISO 2008b)). These threshold (or reference) values are used in order to decide whether a waste sample tested at a specific dilution has ecotoxic effects or not.

\section{RESULTS}

\subsection{Aquatic tests}

\subsubsection{Umu genotoxicity test}

In Table 9, the results of these genotoxicity tests are summarized. All tests were valid according to the ISO standard. In one test (No. 0801 16) the induction rate could not be determined due to cytotoxicity. All tests were performed with (+S9) and without (-S9) metabolic activation.

\subsubsection{Green algae growth test}

The results of the Algae tests are given in Table 10. All tests were valid according to the ISO standard. Effects of up to $100 \%$ were found in all dilution steps in four samples (Nos. 0603 16; 0801 16; 1908 14; 1912 12. In addition, complete inhibition was found in the samples 100117 and 191205 in the two higher solutions (D2 and D4). No effects on Algae did occur in the samples 0105 05, 1701 07, 170504 and 170508 . Regularly, dose-response relationships were observed.

\subsubsection{Daphnia magna test}

An overview of the results of tests with water fleas is given in Table 11. All tests were valid according to the ISO standard. The daphnids reacted most strongly in four samples (Nos. 0801 16; 1001 17; 1201 17; 1912 05). Very rarely - actually just once (No. 0603 16) - a dose-response relationship was visible. In all other samples, no - or almost none (No. 1912 07-A) - effects on daphnids did occur. No other test showed such a strong dichotomy: either a waste did strongly affect the test organisms or no effect at all was observed.

\subsubsection{Summary of aquatic results}

In Table 12 all aquatic results are summarized. In the genotoxicity tests no effects at all were observed. In contrast, out of 23 waste samples 13 of them were identified as ecotoxic in the Algae tests. The results of the daphnid tests were different - only five samples have to be classified as ecotoxic when using this test system.

TABLE 8: Overview on the effect criteria for the individual tests as given in the literature, to be used as threshold (or reference) values for the ecotoxicological hazard assessment of wastes. These dilution rates of waste in the culture medium and these biological effects are taken as reference in this study to classify waste as ecotoxic.

\begin{tabular}{l|l} 
Test name and guideline & Ecotoxic if \\
\hline Umu test (ISO $13829(2000))$ & IR $>1.5$ at dilution 25\% (LID 4) \\
\hline Algae test:(ISO $6341(1996))$ & Effect $>25 \%$ at dilution 25\% (LID 4) \\
\hline Daphnia magna test (ISO 8692 (2004a)) & Effect $>20 \%$ at dilution 25\% (LID 4) \\
\hline Arthrobacter globiformis test (ISO 18187 (2016)) & Effect $>30 \%$ at dilution $12.5 \%$ (LID 8) \\
\hline Plant growth test ISO 11269-2 (2008b)) & Effect $>80 \%$ at dilution 12.5\% (LID 8) \\
\hline Earthworm Avoidance Test (ISO 17512-1 (2008a)) & \\
\hline
\end{tabular}


TABLE 9: Induction rates of the umuC-Gen (without pH adjustment) in the genotoxicity test with waste eluates of 23 different waste materials. Effect criterion: IR $\geq 1.5$. * No IR determined because of cytotoxicity. N.d. Not determined. Tests showing effects at dilution step 6 or higher are indicated as dark-shaded. S9: rat liver extract; used for metabolic activation of the bacteria.

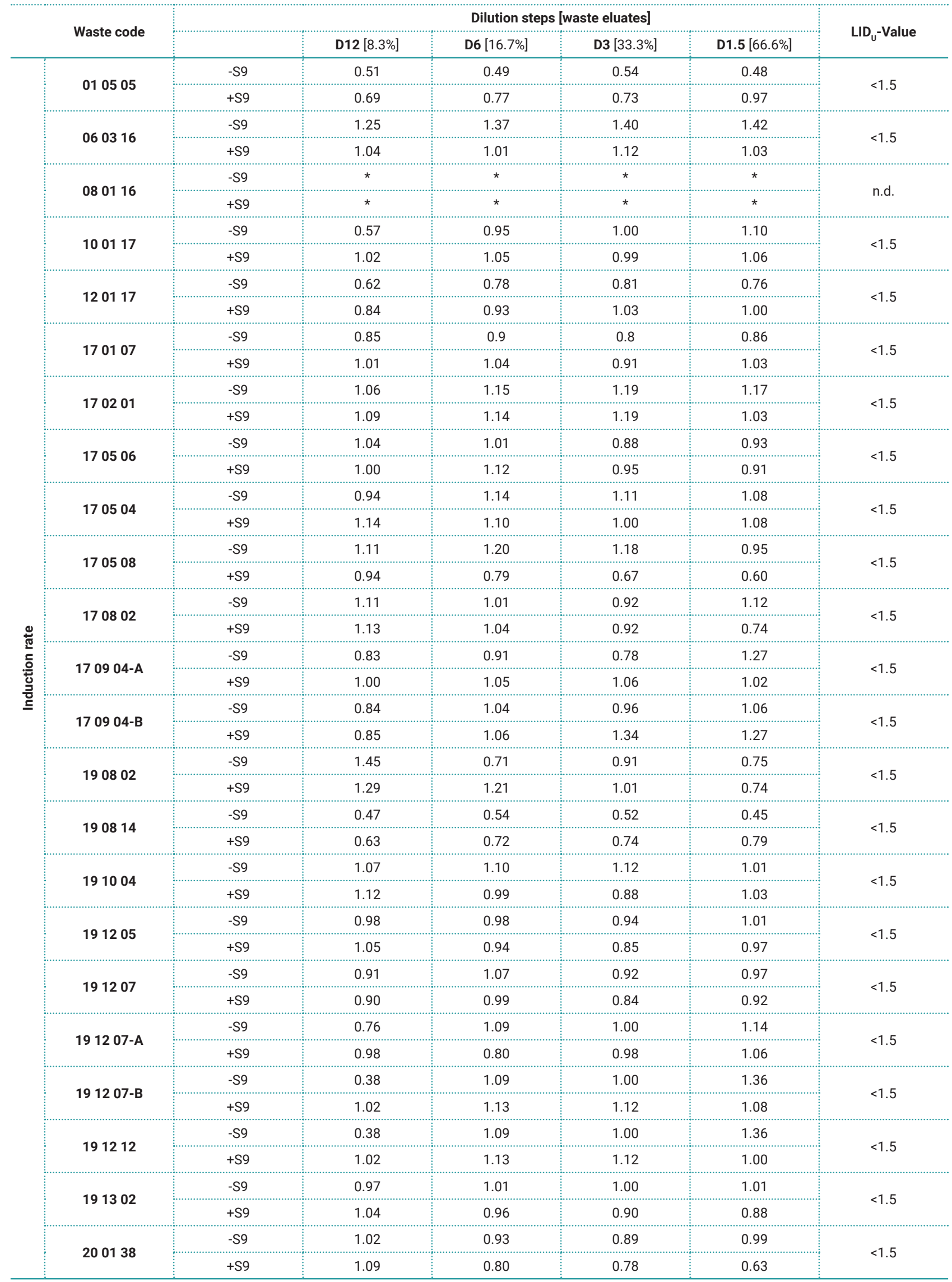


TABLE 10: Inhibition (in \% of the control) of the growth of Pseudokirchneriella subcapitata in the Algae test with waste eluates of different waste materials. Effect criterion: 25\%. Tests showing effects at dilution step 8 or higher are indicated as dark-shaded.

\begin{tabular}{|c|c|c|c|c|c|}
\hline & \multirow{2}{*}{ Waste code } & \multicolumn{3}{|c|}{ Dilution steps [waste eluates] } & \multirow{2}{*}{ LID $_{A}$-value } \\
\hline & & D8 [12.5\%] & D4 [25\%] & D2 [50\%] & \\
\hline \multirow{23}{*}{ 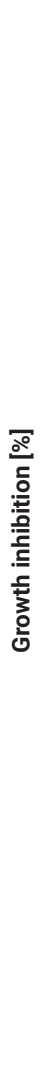 } & 010505 & -16 & -15 & -5 & 2 \\
\hline & 060316 & 82 & $>100$ & $>100$ & $>8$ \\
\hline & 080116 & $>100$ & $>100$ & $>100$ & $>8$ \\
\hline & 100117 & 1 & $>100$ & $?$ & 8 \\
\hline & 120117 & 67 & 85 & $>100$ & $>8$ \\
\hline & 170107 & -1.4 & 1.6 & 1.0 & 2 \\
\hline & 170201 & 13 & 41 & $>100$ & 8 \\
\hline & 170504 & -1 & -3 & 5 & 2 \\
\hline & 170506 & 0 & 9 & 53 & 4 \\
\hline & 170508 & -4 & -4 & -2 & 2 \\
\hline & 170802 & 7 & 3 & 21 & 4 \\
\hline & 1709 04-A & 39 & 44 & 52 & $>8$ \\
\hline & 1709 04-B & 0 & 9 & 42 & 4 \\
\hline & 190802 & 5 & 18 & 71 & 4 \\
\hline & 190814 & $>100$ & $>100$ & $>100$ & $>8$ \\
\hline & 191004 & 2 & 12 & $>100$ & 4 \\
\hline & 191205 & 34 & $>100$ & $>100$ & $>8$ \\
\hline & 191207 & 30 & 33 & 41 & $>8$ \\
\hline & 1912 07-A & 13 & 18 & 44 & 4 \\
\hline & 1912 07-B & 18 & 41 & 76 & 8 \\
\hline & 191212 & $>100$ & $>100$ & $>100$ & $>8$ \\
\hline & 191302 & 13 & 28 & 50 & 8 \\
\hline & 200138 & 31 & 44 & 85 & $>8$ \\
\hline
\end{tabular}

\subsection{Terrestrial tests}

\subsubsection{Arthrobacter globiformis test}

In Table 13, the results of the tests with this bacterial test are summarized. In one test (No. 0105 05) an additional pasteurization was performed because of the high microbial activity of this sample. In one other test (No. 10 01 17) no dose-response relationship was observed. All tests were valid according to the ISO standard. No waste type caused a $100 \%$ effect on the dehydrogenase activity of A. globiformis. However, in 10 samples (Nos. 0105 05; 0801 16; 1001 17; 1201 17; 1702 01; 19 12 07; 1912 07-A; 1912 07-B; 1912 12; 2001 38) the dehydrogenase activity was lower than the control by $>30 \%$. In contrast, in seven samples no effect was found in all dilution steps. Dose-response relationships were almost never observed. A clear increase of the dehydrogenase active did not occur. Despite the small amount of waste in these tests $(0.6 \mathrm{~g})$ these results confirm the robustness of this test. However, the small sample size may have had an influence on the strong differentiation of the test results: only in two tests and LID-value of 8 was observed - all others were either very toxic or not toxic

\subsubsection{Higher plant test (B. napus)}

In Table 14, the results of the tests with the plant $B$. napus test are summarized. All tests were valid according to the ISO standard. In three tests (Nos. 0603 16; 0801 16; 1908 14) no seed germination (or at least no growth of the seedlings did occur) was observed. In addition, effects higher than $30 \%$ were observed in ten samples at all dilution steps (Nos. 0105 05; 1001 17; 1702 01; 17 08 02; 1709 04; 1709 04-B; 1912 07; 1912 07-A; 1912 07-B; 2001 38). In case effects did occur, they followed a dose-response-relationship. Only in eight tests no or low (i.e. $<30 \%$ ) effects were found. Very conspicuous is sample No. 1705 06, (dredged material without contaminants) which caused a strong increase of growth; i.e. probably it contained nutrients.

\subsubsection{Earthworm avoidance test}

In Table 15, the results of the tests with the earthworm E. fetida are summarized. All tests were valid according to the ISO standard. Only in one test an avoidance behavior of $100 \%$ in all dilutions was observed (No. 0801 16). An avoidance behavior of more than $80 \%$ did occur in six samples (Nos. 0105 05; 0603 16; 1001 17; 1702 01; 1709 04-A; 200138$)$. No avoidance effect was visible in six tests (Nos. 1705 04; 1705 06; 1908 02; 1913 02). No dose-response relationship was observed in four samples (Nos. 1705 08; 1912 07, 1912 07-B; 2001 38). In some tests, several samples seemed to be attractive the earthworms (No. 190802 and 1913 02) - especially at higher dilution steps (D8 and D16). 
TABLE 11: Immobilization [\%] of 20 juvenile water fleas (per test vessel) in the Daphnia-test with waste eluates of 23 different waste materials. Effect criterion: 20\%. Tests showing effects at dilution step 8 or higher are indicated as dark-shaded.

\begin{tabular}{|c|c|c|c|c|c|}
\hline & \multirow{2}{*}{ Waste code } & \multicolumn{3}{|c|}{ Dilution steps [waste eluates] } & \multirow{2}{*}{ LID $_{\mathrm{D}}$-value } \\
\hline & & D8 [12.5\%] & D4 [25\%] & D2 [50\%] & \\
\hline \multirow{23}{*}{ 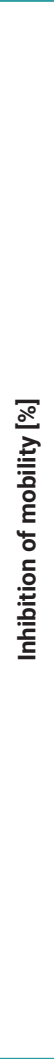 } & 010505 & 5 & 0 & 0 & 2 \\
\hline & 060316 & 5 & 45 & 100 & 8 \\
\hline & 080116 & 100 & 100 & 100 & $>8$ \\
\hline & 100117 & 100 & 100 & 100 & $>8$ \\
\hline & 120117 & 90 & 100 & 100 & $>8$ \\
\hline & 170107 & 0 & 0 & 5 & 2 \\
\hline & 170201 & 0 & 5 & 0 & 2 \\
\hline & 170504 & 0 & 0 & 0 & 2 \\
\hline & 170506 & 0 & 0 & 0 & 2 \\
\hline & 170508 & 0 & 20 & 0 & 2 \\
\hline & 170802 & 0 & 10 & 0 & 2 \\
\hline & $170904-A$ & 0 & 0 & 5 & 2 \\
\hline & 1709 04-B & 0 & 0 & 0 & 2 \\
\hline & 190802 & 0 & 5 & 0 & 2 \\
\hline & 190814 & 0 & 0 & 0 & 2 \\
\hline & 191004 & 0 & 0 & 0 & 2 \\
\hline & 191205 & 50 & 80 & 75 & $>8$ \\
\hline & 191207 & 0 & 0 & 0 & 2 \\
\hline & 1912 07-A & 0 & 0 & 75 & 4 \\
\hline & 1912 07-B & 5 & 5 & 5 & 2 \\
\hline & 191212 & 0 & 0 & 0 & 2 \\
\hline & 191302 & 0 & 0 & 0 & 2 \\
\hline & 200138 & 5 & 0 & 0 & 2 \\
\hline
\end{tabular}

TABLE 12: Results of the aquatic tests (LID-values) with waste eluates. * No IR determined because of cytotoxicity.

\begin{tabular}{|c|c|c|c|}
\hline Waste code & Umu-Test: LID ${ }_{\mathrm{U}}(\mathrm{S}$. choleraesius) & Algae: LID $_{A}(P$. subcapitata) & Daphnia: LID ${ }_{D}$ (D. magna) \\
\hline 010505 & $<1.5$ & 2 & 2 \\
\hline 060316 & $<1.5$ & $>8$ & 8 \\
\hline 080116 & * & $>8$ & $>8$ \\
\hline 100117 & $<1.5$ & 8 & $>8$ \\
\hline 120117 & $<1.5$ & $>8$ & $>8$ \\
\hline 170107 & $<1.5$ & 2 & 2 \\
\hline 170201 & $<1.5$ & 8 & 2 \\
\hline 170504 & $<1.5$ & 2 & 2 \\
\hline 170506 & $<1.5$ & 4 & 2 \\
\hline 170508 & $<1.5$ & 2 & 2 \\
\hline 170802 & $<1.5$ & 4 & 2 \\
\hline $170904-A$ & $<1.5$ & $>8$ & 2 \\
\hline $170904-B$ & $<1.5$ & 4 & 2 \\
\hline 190802 & $<1.5$ & 4 & 2 \\
\hline 190814 & $<15$ & $>8$ & 2 \\
\hline 191004 & $<1.5$ & 4 & 2 \\
\hline 191205 & $<1.5$ & $>8$ & $>8$ \\
\hline 191207 & $<1.5$ & $>8$ & 2 \\
\hline 1912 07-A & $<1.5$ & 4 & 4 \\
\hline 1912 07-B & $<1.5$ & 8 & 2 \\
\hline 191212 & $<1.5$ & $>8$ & 2 \\
\hline 191302 & $<1.5$ & 8 & 2 \\
\hline 200138 & $<1.5$ & $>8$ & 2 \\
\hline
\end{tabular}


TABLE 13: Inhibition of the dehydrogenase activity of A. globiformis in the Bacteria contact test with 23 different waste materials; effect criterion $30 \%$. Lightly-shaded cells: no dose-response relationship. * Additional pasteurization performed. N.d.: Not determined (light-shaded cells). Tests showing effects at dilution step 16 or higher are indicated as dark-shaded.

\begin{tabular}{|c|c|c|c|c|c|}
\hline & \multirow{2}{*}{ Waste code } & \multicolumn{3}{|c|}{ Dilution steps } & \multirow{2}{*}{ LID $_{B}$-value } \\
\hline & & D16 [6.25\% Waste] & D8 [12.5\% Waste] & D4 [25\% Waste] & \\
\hline \multirow{23}{*}{ 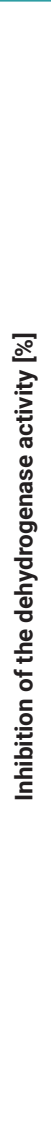 } & 010505 * & 43.5 & 55.3 & 60.6 & $>16$ \\
\hline & 060316 & 27.4 & 61.3 & 80.6 & 16 \\
\hline & 080116 & 83.5 & 91.6 & 96.1 & $>16$ \\
\hline & 100117 & 98.1 & 92.7 & 81.9 & $>16$ \\
\hline & 120117 & 30.7 & 43.6 & 79.6 & $>16$ \\
\hline & 170107 & -1.9 & 16.6 & 34.5 & 8 \\
\hline & 170201 & 46.8 & 65.8 & 83.3 & $>16$ \\
\hline & 170504 & 3.4 & -0.6 & -4.6 & 4 \\
\hline & 170506 & -3.5 & -0.9 & 5.9 & 4 \\
\hline & 170508 & -0.9 & 2.8 & 13.3 & 4 \\
\hline & 170802 & 1.3 & -5.2 & 5.3 & 4 \\
\hline & 1709 04-A & 0.8 & 44.9 & n.d. & 16 \\
\hline & 1709 04-B & 33.3 & 42.6 & n.d. & $>16$ \\
\hline & 190802 & 10.2 & 8.4 & 37.2 & 8 \\
\hline & 190814 & 4.5 & 33.0 & 42.0 & 16 \\
\hline & 191004 & 25.3 & 33.2 & 75.1 & 16 \\
\hline & 191205 & 1.3 & 3.8 & 28.5 & 4 \\
\hline & 191207 & 58.4 & 82.1 & 85.8 & $>16$ \\
\hline & 1912 07-A & 60.9 & 84.9 & 94.8 & $>16$ \\
\hline & 1912 07-B & 75.8 & 93.9 & 96.1 & $>16$ \\
\hline & 191212 & 33.7 & 52.7 & 77.3 & $>16$ \\
\hline & 191302 & 8.0 & 10.7 & 13.4 & 4 \\
\hline & 200138 & 53.2 & 83.9 & 88.0 & $>16$ \\
\hline
\end{tabular}

\subsubsection{Summary of terrestrial results}

In Table 16 all terrestrial results are summarized. No test failed. In the Arthrobacter test 15 wastes were identified as ecotoxic, in the plant tests 14 and in the earthworm tests just six.

\subsection{Summary: classification of all test results (aquat- ic and terrestrial tests together)}

In this chapter, the results of the aquatic and terrestrial tests are presented together (Table 17). Afterwards, the assessment principles proposed by Pandard and Römbke (2013) will be applied (e.g. using the same threshold values and limit concentrations) with one exception: instead of the luminescent bacteria test (ISO 11348-3 (2007a) the genotoxicity test (ISO 13829 (2000)) was used. However, the latter one did not show any effects. Therefore, in the following the classification will be performed without the bacterial tests in order to avoid a bias when comparing the aquatic and terrestrial effects. However, and referring to Table 13, it should be kept in mind that in the terrestrial bacterial tests 15 out of 23 wastes were classified as ecotoxic.

According to the tiered approach proposed by Pandard and Römbke (2013), the results of the aquatic tests are considered first. Out of the 23 wastes tested 13 breached the LID of 4 . Algae reacted more sensitively since they were affected in all these 13 cases. Only five wastes were toxic for water flea. No waste did only affect the daphnids. The different sensitivity pattern of these two organisms is also shown by the fact that the Algae were not affected at all by five wastes ( $L I D=2$ ) and showed small effects in tests with another five wastes (LID $=4)$. In contrast, the daphnids showed a strong yes/no pattern: in 17 tests, there was no effect $(L I D=2)$, meaning that only one waste caused a small effect. In summary, in this sample of wastes (with one exception all of them had no mirror entries) $57 \%$ of them are ecotoxic.

In the terrestrial tests 14 out of 23 wastes are considered to be ecotoxic. Again, the sensitivity of the two species differs considerably: all of these 14 waste samples were toxic to plants, but only six of them affected the earthworms strongly. Eight wastes did not affect the plants and just one caused a small effect. The respective numbers for the earthworms are 13 and four. No waste was classified as ecotoxic only in the earthworm tests. Looking only at the outcome of the terrestrial tests $61 \%$ of all wastes did affect terrestrial organisms. According to the proposed scheme, only the ten wastes evaluated as non-ecotoxic in the aquatic tests are assessed in the second step, using the results of the terrestrial tests. Five 
TABLE 14: Reduction of biomass (in comparison to the control in \%) of B. napus (turnip) in the plant growth tests with 23 different waste materials; effect criterion $30 \%$. No conspicuous observations were made. * No seeds did germinate at all. Tests showing effects at dilution step 16 or higher are indicated as dark-shaded.

\begin{tabular}{|c|c|c|c|c|c|}
\hline & \multirow{2}{*}{ Waste code } & \multicolumn{3}{|c|}{ Dilution steps } & \multirow{2}{*}{ LID $_{P}$-value } \\
\hline & & D16 [6.25\% Waste] & D8 [12.5\% Waste] & D4 [25\% Waste] & \\
\hline \multirow{23}{*}{ 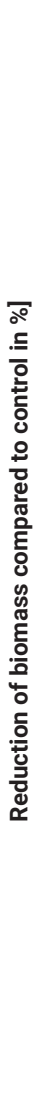 } & 010505 & 85.5 & 84.4 & 82.4 & $>16$ \\
\hline & 060316 & * & * & * & $>16$ \\
\hline & 080116 & * & * & * & $>16$ \\
\hline & 100117 & 53.4 & 79.2 & 93.3 & $>16$ \\
\hline & 120117 & -4.4 & 7.4 & -3.2 & 4 \\
\hline & 170107 & -11.8 & -15.9 & 12.4 & 4 \\
\hline & 170201 & 54.0 & 69.8 & 89.8 & $>16$ \\
\hline & 170504 & -22.8 & -21.3 & -18.9 & 4 \\
\hline & 170506 & -46.0 & -61.3 & -65.7 & 4 \\
\hline & 170508 & 9.8 & 13.9 & 11.5 & 4 \\
\hline & 170802 & 36.1 & 54.6 & 63.7 & $>16$ \\
\hline & 1709 04A & 94.9 & 97.0 & 98.0 & $>16$ \\
\hline & 1709 04B & 68.7 & 72.2 & 82.5 & $>16$ \\
\hline & 190802 & -2.7 & -0.6 & -2.7 & 4 \\
\hline & 190814 & * & * & * & $>16$ \\
\hline & 191004 & 22.6 & 49.8 & 68.2 & 16 \\
\hline & 191205 & -1.5 & 5.5 & 7.2 & 4 \\
\hline & 191207 & 76.5 & 82.1 & 87.9 & $>16$ \\
\hline & 1912 07-A & 72.5 & 78.6 & 81.0 & $>16$ \\
\hline & 1912 07-B & 63.4 & 81.2 & 80.5 & $>16$ \\
\hline & 191212 & 21.7 & 21.6 & 45.8 & 8 \\
\hline & 191302 & -31.2 & -3.6 & 28.8 & 4 \\
\hline & 200138 & 63.0 & 70.6 & 87.9 & $>16$ \\
\hline
\end{tabular}

out of the 10 wastes caused effects in the tests with soil organisms. Therefore, in total 18 wastes out of $23(=78 \%)$ are classified as hazardous following the concept of Pandard and Römbke (2013).

However, when comparing those nine cases in which either aquatic or terrestrial organisms reacted more sensitively it seems that sensitivity does not differ between both organism groups, since in five tests aquatic organisms were reacting stronger than their terrestrial counterparts - and in four tests this situation was just the other way around. Finally, the inclusion of the bacterial results should be briefly discussed. As mentioned earlier, the inclusion of the genotoxicity data (no effects at all) would not change the number of wastes classified as being hazardous from aquatic testing. Assuming that instead the luminescent Bacteria test would have been used either no change or an increase in ecotoxic wastes would happen. However, in the case of the terrestrial bacteria test we do have data (see Table 14): in 15 out of 23 tests with A. globiformis strong effects were found, but with two exceptions (Nos. 1201 17 and 1912 12) those were samples which already were identified as toxic in the plant or earthworm tests. In addition, both exceptions were also toxic to aquatic organisms, meaning that the overall results would not change.

\subsection{Discussion of the toxicity of the wastes used in this project}

Despite the fact that the quite high number of wastes tested here more data are needed in order to cover the full range of different waste types. This aim could either be reached by closing gaps regarding waste types, or by testing samples the same waste types as done here but coming from other sites in order to get an overview how much this property differs within one waste type.

The ecotoxicological test methods used here are robust, practical and reliable. Only one out of 24 samples (No. 11 01 10: highly condensed but still fluid galvanic sludge) could not be tested, partly because of its physico-chemical properties, partly because of its unknown human toxicology. Therefore, from a technical point of view the use of ecotoxicological test methods is recommended.

The results of such tests are neither correlated between them (i.e. each test has its own "effect profile") nor is the information gained redundant to information from other sources (e.g. chemistry) regarding the question whether a specific waste is classified as hazardous or not. Twenty wastes are mirror entries and can be hazardous or not depending on the concentration of hazardous substances. In contrast, in ecotoxicological tests almost $75 \%$ all test- 
TABLE 15: Avoidance behavior (in comparison to the control in \%) of the earthworm E. fetida in the earthworm avoidance tests with 23 different waste materials; effect criterion $80 \%$. All tests were valid according to the ISO standard. Lightly-shaded cells: no dose-response relationship. Tests showing effects at dilution step 8 or higher are indicated as dark-shaded.

\begin{tabular}{|c|c|c|c|c|c|}
\hline & \multirow{2}{*}{ Waste code } & \multicolumn{3}{|c|}{ Dilution steps } & \multirow{2}{*}{ LID $_{R}$-value } \\
\hline & & D16 [6.25\% Waste] & D8 [12.5\% Waste] & D4 [25\% Waste] & \\
\hline \multirow{23}{*}{ 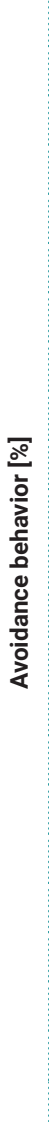 } & 010505 & 88 & 92 & 100 & $>16$ \\
\hline & 060316 & 68 & 88 & 100 & 16 \\
\hline & 080116 & 100 & 100 & 100 & $>16$ \\
\hline & 100117 & 72 & 92 & 100 & 16 \\
\hline & 120117 & 14 & 68 & 88 & 8 \\
\hline & 170107 & -2 & 40 & 88 & 8 \\
\hline & 170201 & 52 & 82 & 88 & 16 \\
\hline & 170504 & 0 & 4 & 32 & 4 \\
\hline & 170506 & -24 & 40 & 20 & 4 \\
\hline & 170508 & 48 & 40 & 36 & 4 \\
\hline & 170802 & 10 & 52 & 56 & 4 \\
\hline & 1709 04-A & 60 & 64 & 94 & 8 \\
\hline & 1709 04-B & -32 & 44 & 52 & 4 \\
\hline & 190802 & -68 & -68 & -40 & 4 \\
\hline & 190814 & 16 & 28 & 56 & 4 \\
\hline & 191004 & 28 & 76 & 90 & 8 \\
\hline & 191205 & -10 & 8 & 30 & 4 \\
\hline & 191207 & 20 & 66 & 52 & 4 \\
\hline & 1912 07-A & -34 & -16 & 4 & 4 \\
\hline & 1912 07-B & 52 & -28 & 24 & 4 \\
\hline & 191212 & 22 & 36 & 46 & 4 \\
\hline & 191302 & -60 & -22 & 21 & 4 \\
\hline & 200138 & 44 & 84 & 78 & 16 \\
\hline
\end{tabular}

ed wastes are classified as hazardous. So, it seems that this kind of testing is more sensitive in identifying wastes which could be ecotoxicologically hazardous.

Right now, it is impossible to say whether the results of this study are representative for the relationship between ecotoxicological testing and the classification of wastes according to the List of Wastes in general. However, further ecotoxicological tests with a broader range of wastes, trying to cover the range of the waste types and subtypes, are recommended in order to get a better understanding of the hazard properties of wastes. In case such studies will be performed a chemical characterization of the test samples is highly recommended. Assuming that such a data set will be available, the suitability and robustness of the different classification approaches could be assessed and recommendations for legal handling could be formulated.

\section{DISCUSSION}

\subsection{Test performance, species selection and species sensitivity}

\subsubsection{Test substrate characterization}

There is a need for an improved description of the sampling, handling (especially the pre-treatment, e.g. the particle size) and storage of waste samples before they are used in ecotoxicological tests. Without that kind of information comparability of results is hampered. In addition, the properties of the individual waste samples should be characterized as good as possible, both in terms of their physical appearance as well as their chemical composition. Data from general data bases (as used here) are not sufficient. Despite the fact that each waste sample by definition differs from each other such information could be used to understand better the reasons for ecotoxicity of waste samples.

\subsubsection{Selection of the ecotoxicological test methods and species}

Regarding the composition of the test battery it is recommended to follow all recommendations of Pandard and Römbke (2013). This includes the testing of waste eluates with the bacterial luminescent test (ISO 11348-3 (2007a) instead of the umu genotoxicity test (ISO 13829 (2000), as originally proposed after the ring test (Moser \& Römbke 2009), for the following reasons:

- Genotoxicity is a very specific endpoint which seems to be rarely relevant for wastes, at least to my experience no sample tested in our lab did show any signs of genotoxicity; 
TABLE 16: Results of the terrestrial tests (LID-values) with solid wastes.

\begin{tabular}{|c|c|c|c|}
\hline Waste code & $\begin{array}{l}\text { Arthrobacter Test: } \text { LID }_{\text {B }} \\
\text { (A. globiformis) }\end{array}$ & $\begin{array}{l}\text { Higher Plant Test: LID } \\
\quad(P . \text { subcapitata) }\end{array}$ & $\begin{array}{c}\text { Earthworm Avoi-dance Test: } \text { LID }_{\mathrm{R}} \\
\text { (E. fetida) }\end{array}$ \\
\hline 010505 & $>16$ & $>16$ & $>16$ \\
\hline 060316 & 16 & $>16$ & 16 \\
\hline 080116 & $>16$ & $>16$ & $>16$ \\
\hline 100117 & $>16$ & $>16$ & 16 \\
\hline 120117 & $>16$ & 4 & 8 \\
\hline 170107 & 8 & 4 & 8 \\
\hline 170201 & $>16$ & $>16$ & 16 \\
\hline 170504 & 4 & 4 & 4 \\
\hline 170506 & 4 & 4 & 4 \\
\hline 170508 & 4 & 4 & 4 \\
\hline 170802 & 4 & $>16$ & 4 \\
\hline 1709 04-A & 16 & $>16$ & 8 \\
\hline 1709 04-B & $>16$ & $>16$ & 4 \\
\hline 190802 & 8 & 4 & 4 \\
\hline 190814 & 16 & $>16$ & 4 \\
\hline 191004 & 16 & 16 & 8 \\
\hline 191205 & 4 & 4 & 4 \\
\hline 191207 & $>16$ & $>16$ & 4 \\
\hline 1912 07-A & $>16$ & $>16$ & 4 \\
\hline 1912 07-B & $>16$ & $>16$ & 4 \\
\hline 191212 & $>16$ & 8 & 4 \\
\hline 191302 & 4 & 4 & 4 \\
\hline 200138 & $>16$ & $>16$ & 16 \\
\hline
\end{tabular}

- At the time of the European Waste Ringtest there was no real alternative for a standardized microbial test in soil available.

This situation has changed considerably: the Arthrobacter Test, originally developed for sedimenst, was modified successfully in order to perform it both in soils and wastes (e.g. Marques et al. 2018). Still, the genotoxicity test is an option for those wastes where there are hints that the waste to be tested may contain genotoxic components. Focusing on the aquatic compartment Weltens et al. (2012) proposed it as screening tests for the hazard classification of wastes in a similar test battery, i.e. the Algae growth inhibition test, the Daphnia immobilization test and, in addition, the fish larval mortality test. These authors discuss the luminescent Bacteria test as a fast alternative.

\subsubsection{Sensitivity of the selected ecotoxicological tests}

Looking at the outcome of this project it could be argued that it would be sufficient to use in the future only those tests which have been most sensitive. In detail, the overall number of wastes affecting organisms would not change if only the Algae and the Arthrobacter tests would have been performed here. However, this conclusion is premature because it is based on just 23 waste samples. Experiences from other regulatory areas, in particular the testing of chemicals, has shown that it is not possible to identify "the most sensitive species" because it simply does not exist (Cairns 1986).

When studying different wastes in the international ring test (Moser and Römbke 2009) or fly ashes (Römbke and Moser 2007) with the umu test rarely genotoxicity was found. However, Brackemann et al. (2000) report genotoxic reactions in an acid eluate prepared from stoker-fired furnace ash as well as in three wastes from chemical industry. Since genotoxicity is a very important endpoint the low number of data should not be taken as an excuse to disregard this test.

The ecological relevance and sensitivity of the Algae test is often considered as high (Deventer et al. 2004). For example, they reacted often more sensitively in eluates from different wastes (mainly ashes) than daphnids or luminescent Bacteria (Kaneko 1996; Lapa, 2002a; Lapa $2002 b)$. Therefore, they are regularly proposed as part of an ecotoxicological test battery for wastes (e.g. Pandard et al. 2006; Moser and Römbke 2009). However, it is known that the two species recommended in the Algae tests could react differently when exposed to the same waste (Moser and Römbke 2009).

Tests with the water-flea Daphnia magna have often been used for waste testing, in particular with waste incineration ashes (e.g. Kaneko 1996; Triffault-Bouchet et al. 2003; LFU 2004; Pandard et al. 2006; Römbke and Moser 2007). Results from the international ringtest confirm the 
TABLE 17: Classification of the individual tests using the threshold values and limit concentrations described above. Grey cells: Ecotoxicological effects higher than the test-specific threshold values did occur at the respective limit concentrations (LID aquatics $=>4$; LID terrestrial > 8). Black cells: ecotoxicologically hazardous according to the HP 14 property. Note that the bacterial tests were not included since the umu-test did not show any effects.

\begin{tabular}{|c|c|c|c|c|c|c|c|}
\hline \multirow[b]{2}{*}{ Waste code } & \multicolumn{3}{|c|}{ Aquatic tests } & \multicolumn{3}{|c|}{ Terrestrial tests } & \multirow{2}{*}{$\begin{array}{c}\text { Overall } \\
\text { Hazard } \\
\text { evaluation }\end{array}$} \\
\hline & LID $_{A}$ & LID $_{D}$ & $\begin{array}{l}\text { Ecotox. } \\
\text { LID > } 4\end{array}$ & LID $_{\mathrm{p}}$ & LID $_{R}$ & $\begin{array}{l}\text { Ecotox. } \\
\text { LID }>8\end{array}$ & \\
\hline 010505 & 2 & 2 & & $>16$ & $>16$ & & \\
\hline 060316 & $>8$ & 8 & & $>16$ & 16 & & \\
\hline 080116 & $>8$ & $>8$ & & $>16$ & $>16$ & & \\
\hline 100117 & 8 & $>8$ & & $>16$ & 16 & & \\
\hline 120117 & $>8$ & $>8$ & & 4 & 8 & & \\
\hline 170107 & 2 & 2 & & 4 & 8 & & \\
\hline 170201 & 8 & 2 & & $>16$ & 16 & & \\
\hline 170504 & 2 & 2 & & 4 & 4 & & \\
\hline 170506 & 4 & 2 & & 4 & 4 & & \\
\hline 170508 & 2 & 2 & & 4 & 4 & & \\
\hline 170802 & 2 & 2 & & $>16$ & 4 & & \\
\hline $170904-A$ & $>8$ & 2 & & $>16$ & 8 & & \\
\hline 1709 04-B & 4 & 2 & & $>16$ & 4 & & \\
\hline 190802 & 4 & 2 & & 4 & 4 & & \\
\hline 190814 & $>8$ & 2 & & $>16$ & 4 & & \\
\hline 191004 & 4 & 2 & & 16 & 8 & & \\
\hline 191205 & $>8$ & $>8$ & & 4 & 4 & & \\
\hline 191207 & $>8$ & 2 & & $>16$ & 4 & & \\
\hline 1912 07-A & 4 & 4 & & $>16$ & 4 & & \\
\hline 1912 07-B & 8 & 2 & & $>16$ & 4 & & \\
\hline 191212 & $>8$ & 2 & & 8 & 4 & & \\
\hline 191302 & 8 & 2 & & 4 & 4 & & \\
\hline 200138 & $>8$ & 2 & & $>16$ & 16 & & \\
\hline
\end{tabular}

high practicability and sensitivity of this test system. It was by far the most often performed test but at the same time the one with the lowest number of invalid data sets (Moser and Römbke 2009). In the light of these experiences the low sensitivity in this study is difficult to explain. It might be that water flea react mainly to heavy metals (Seco et al. 2003), which - by chance - were not so often occurring in the 23 wastes tested.

Despite the fact that the Arthrobacter test has been used for quite some time (mainly in sediments) it has only been standardized for soils quite recently. Therefore, the number of experiences in waste testing are limited, mainly with incineration ashes (Deventer et al. 2004; Römbke et al. 2009). Positive experiences in the international ring test (Moser and Römbke 2009) and in a recent interlaboratory comparison test (Marques et al. 2018). In particular its high practicability (short duration, low costs, high sensitivity) has increased its usage.

When testing the effects of contaminant soils on plants often the dicotyledonous species Brassica rapa (or $B$. napus) is reacting most sensitively (Wilke et al. 1998; Kalsch et al. 2006b). In addition, the test is very robust, meaning that it is a regular part of terrestrial ecotoxicologi- cal test batteries. In fact, while the number of plant test with wastes is still limited it is the test most often performed with solid waste samples. Again, different ashes are the best studied samples (Wong and Wong 1989; Deventer al. 2004; Römbke and Moser 2007). It could also be shown that ashes with different physico-chemcial properties do cause different effects on plants (Quilici et al. 2004).

The earthworm avoidance test has been developed and standardized about ten years ago (ISO 17512-1 (2007)), i.e. the amount of data regarding its use for waste testing is limited. However, when used in the international Ringtest it became clear that it is much more sensitive than the earthworm acute test (ISO 11268-1 (1993)), which was proposed earlier for this task (Moser and Römbke 2009). However, the results were often variable - an observation which is known from tests with contaminated soils (Hund-Rinke et al. 2003). This might be caused by the fact that the worms do not only react to toxic contaminants but also to physico-chemical properties (Natal-da-Luz et al. 2008). Kobeticova et al. (2010) confirm the suitability of the earthworm avoidance test for waste evaluation, also pointing out that other oligochaete species such as enchytraeid seem to be less sensitive. 
Huguier et al. (2015) studied a wide range of (mainly) organic wastes in tests with various aquatic and terrestrial species (partly with more than one endpoint), trying to identify a suitable test battery. Plants (Avena sativa, Brassia rapa) and earthworms (Eisenia fetida), seem to be suitable for this specific group of wastes. In addition, the authors confirm the good comparability of results from avoidance and reproduction earthworm tests. This information supports the choice made here but cannot easily be transferred to wastes in general.

The information summarized in this chapter confirms that a battery of six test methods (plus, if needed, a genotoxicity test) selected by Pandard and Römbke (2013) is needed for the ecotoxicological characterization of wastes since they react sensitively to different stressors and their interactions.

\subsection{Test design, threshold (reference) and limit values}

\subsubsection{Test design}

Both an "Extended Limit Design" (i.e. testing three (or more) dilution steps with fixed ratios) as well as the EC-approach do allow an ecotoxicological classification of wastes.

In Germany, the LID-approach (= Lowest Ineffective Dilution) is widely used for the evaluation of waste waters or contaminated soils, partly because the effort needed is relatively low (e.g. only three dilution steps are needed) (e.g. DiBt 2008). In order to assess the ecotoxicological hazard of a waste sample it is necessary to define a limit concentration, usually given in percent of the overall tested amount (e.g. $12.5 \%=$ LID 8). These limit concentrations cannot be defined based on test results but must be set-up before testing, using the following criteria:

- The limit concentration should be practical when classifying wastes;

- They must be protective, i.e. hazardous wastes must be clearly identifiable.

So far, legally no limit concentration has been fixed. Unfortunately, only few proposals have been found in the literature, mainly addressing aquatic tests (e.g. Kostka-Rick 2004b; DIBt 2008). However, based on these hints and the experiences made in the European Ringtest on Wastes, a $\mathrm{LID}=4$ for the aquatic tests and $\mathrm{a}$ LID $=8$ for the terrestrial tests was proposed as being acceptable (Moser \& Römbke 2009). The LID-approach did work well for this testing and assessment program, but it has its limitations (e.g. it highly depends on the concentrations tested). In any case it was possible to differentiate ecotoxic and non-ecotoxic wastes. Beyond this yes/no-decision it is also possible to assess, how toxic the respective waste or the specific test organism is, since three dilution steps were used. Only results from the umu- test are difficult to be assessed, since genotoxicity seems to be less dose-dependent than other endpoints. In addition, this test reacts only to specific contaminants, making it less sensitive in general.

In ecotoxicology in general the ECx approach is more common since it allows a more detailed but also robust assessment of ecotoxicological effects - as long as the whole response curve (ideally from 0 to $100 \%$ ) is covered. In order to improve the robustness of this classification the use of an ECx design (aiming on the calculation of an EC50 value) would be better. In such a case, more concentrations than just three as in the "Extended Limit Approach" have to be tested (e.g. up to eight). However, when doing so the number of replicates per concentration is lowered, meaning that the overall testing effort would not increase very much. Pandard and Römbke (2013), recommending an ECx-design (i.e. an $\mathrm{EC}_{50}$ as limit concentration), could show that such an approach is reliable and protective. First experiences show that the ecotoxicological characterization of wastes do not differ much between these two methods (Pandard and Römbke 2013). However, the number of such comparisons is still very low. Therefore, from a scientific point-of-view the determination of an EC50 is the better and more robust option, being in-line with other areas of ecotoxicology (e.g. the risk assessment of chemicals).

\subsubsection{Threshold (reference) values}

The threshold values for the individual tests (e.g. $20 \%$ effect on the main test endpoint such as immobility in the Daphnia-test) used here are based on ideas firstly published by Moser (2008). Partly they are already mentioned in the respective test standards, partly they are specified in scientific publications focusing on waste classification. Ideally, such threshold values should be based on statistical considerations, but the respective comparable data sets are not (yet) available. Therefore, experiences with soil tests have been used too. In fact, there is a grey zone between contaminated soils and at least some wastes (e.g. in this project: No. 1913 02: Solid wastes from soil remediation other than those listed in 191301 . Soil material strongly contaminated by $\mathrm{PAH}$ and mineral oil, but also $\mathrm{Pb}, \mathrm{Zn}, \mathrm{Cu}, \mathrm{Cr}$ and $\mathrm{PCB})$.

Independently whether the LID- or the ECX-approach is used there is always a third level of decision-making in case a test battery is used: in how many tests have the threshold values to be breached? For example, in order to characterize a waste as being hazardous at least one test has to show an effect on one aquatic or one terrestrial species. Another possibility would be to require effects on one species from each of the three taxonomic groups independently in which medium they had been tested. At this point, again the proposal of Pandard and Römbke (2013) is followed, meaning that a tiered approach is used. One aquatic or one terrestrial test has to show effects higher than the respective threshold value in order to classify the tested waste as hazardous according to the HP 14 property.

There has also been no criterion fixed legally so far regarding the outcome of the whole test battery. Previously - and following a recommendation given in ISO 17616 (ISO 2008b) for the assessment of contaminated soils - it was assumed that a waste is classified as "ecotoxic" in case the threshold values have been breached in one out of six tests. Later on, Pandard and Römbke (2013) modified this strategy (which works well as long as the number of aquatic and terrestrial tests is equal) in a way that the process is divided into two parts: 
1. Assessment based on aquatic biotests: If one of the LID values in the eluate tests (the IR value of $>1.5$ in the umu-test would be handled like a LID-value $>4$ ) is above the proposed threshold values of 4 or 8 , respectively, the waste is classified as hazardous and the overall procedure is stopped.

2. Otherwise, solid waste tests are carried out and the assessment procedure is repeated. The waste is considered as non-hazardous if the results of all biotests are below or equal to the threshold values.

\subsection{Comparison of different approaches regarding the ecotoxicological characterization of wastes}

The chemical composition of the tested wastes is not known. Therefore, it is impossible to calculate whether the respective waste sample has to be classified as "ecotoxic" or not. Alternatively, the List of Waste could be used as a reference, but in that list, only the "absolute" entries can be used to assess the proposed dilutions, meaning that a classification of the waste samples tested here is also not possible.

From the results of the tests (Table 17) and the proposition of dilution and effect rates for ecotoxicity classification (Table 8), 18 wastes are classified as ecotoxic (17 mirror entries and one hazardous 0105 05*), and four wastes are classified as non-ecotoxic (three mirror entries and one non-hazardous 1908 02). In other words, one hazardous waste is classified as ecotoxic, one non-hazardous waste is classified as non-ecotoxic and 20 "mirror entries" are classified 17 times as ecotoxic and three times as non-ecotoxic. Right now, it is impossible to say whether the results of this study are representative for the relationship between ecotoxicological testing and the classification of wastes according to the List of Wastes. However, further ecotoxicological tests with a broader range of wastes, trying to cover the range of the waste types and subtypes, are recommended in order to get a better understanding of the hazard properties of wastes. In case such studies will be performed a chemical characterization of the test samples is highly recommended. Assuming that such a data set will be available, the suitability and robustness of the different classification approaches could be assessed and recommendations for legal handling formulated.

\section{ACKNOWLEDGEMENTS}

I would like to thank all colleagues at ECT GmbH (Adam Scheffczyk, Bernhard Förster, Elisabeth Richter, Marika Goth, Nicola Böffınger, Stephan Jänsch, Thomas Moser), and especially Ralf Ketelhut (Stoffstromdesign) being involved in the testing of the wastes. The project (FKZ 370831 300) was sponsored by the German Federal Environment Agency (UBA), in particular Heidrun Moser. Finally, I would like to highlight the helpful comments of the reviewers of DETRITUS.

\section{REFERENCES}

Becker, L., Scheffczyk, A., Oehlmann, J., Römbke, J. and Moser, T. (2011): Effects of boric acid on varied plants and soil organisms. J. Soils Sediment. 11: 238-248.
Brackemann, H., Hagendorf, U., Hahn, J. and Vogel, U. (2000): Untersuchung von Abfällen mit biologischen Testverfahren zur Bewertung der Wassergefährdung. I. Experimentelle Ergebnisse. Z. Umweltchem. Ökotox. (UWSF) 12: 5-12.

Cairns, J. (1986): The myth of the most sensitive species. BioScience 36: $670-672$.

CEN (Comité Européen de Normalisation) (2003): Characterisation of waste - Leaching - Compliance test for leaching of granular waste materials and sludges - Part 2: One stage batch test at a liquid to solid ratio of $10 \mathrm{l} / \mathrm{kg}$ for materials with particle size below $4 \mathrm{~mm}$ (without or with size reduction). CEN 12457-2. Brussels, Belgium.

CEN (Comité Européen de Normalisation) (2005): Characterization of waste - Preparation of waste samples for ecotoxicity tests. CEN 14735. European Standard, Brussels, Belgium.

CEN (Comité Européen de Normalisation) (2017): Construction products: Assessment of release of dangerous substances - Guidance on the use of ecotoxicity tests applied to construction products. CEN/TR 17105. Brussels, Belgium.

DIBt (Deutsches Institut für Bautechnik) (2008): Merkblatt für die Bewertung der Auswirkungen von Bauprodukten auf Boden und Grundwasser. Berlin.

EC (European Commission) (2000): Commission Decision of 3 May 2000 replacing Decision 94/3/EC establishing a list of wastes pursuant to Article 1(a) of Council Directive 75/442/EEC on waste and Council Decision 94/904/EC establishing a list of hazardous waste pursuant to Article 1(4) of Council Directive 91/689/EEC on hazardous waste. Official Journal of the European Communities, L 226, 6.9.2000, p 3-24.

EU (European Union) (2008): Regulation on classification, labelling and packaging of substances and mixtures, amending and repealing Directives 67/548/EEC and 1999/45/EC, and amending Regulation (EC) No 1907/2006, European Parliament and Council, Art. 95 (EC). L353, 31.12.2008, pp. 1-1355.

EU (European Union) (2014): Commission Regulation (EU) No 1357/2014 of 18 December 2014 replacing Annex III to Directive 2008/98/EC of the European Parliament and of the Council on waste and repealing certain Directives Text with EEA relevance.

EU (European Union) (2017): Council Regulation (EU) 2017/997 of 8 June 2017 amending Annex III to Directive 2008/98/EC of the European Parliament and of the Council as regards the hazardous property HP 14 'Ecotoxic').

Eurelectric (Union of the Electricity Industry) (2016): Study to assess the impacts of different approaches for hazard property "HP 14" on selected waste streams. Eurelectric comments. Report, 8 pp.

Huguier, P. Manier, N., Chabot, L., Bauda, P. and Pandard, P. (2015): Ecotoxicological assessment of organic wastes spread on land: towards a proposal of a suitable test battery. Ecotox. Envir. Safe. 70: 283-293.

Hund-Rinke, K. and Wiechering, H. (2001): Earthworm avoidance test for soil assessment. J. Soils Sediment. 1: 15-20.

ISO (International Organization for Standardization) (2012): Water quality - Determination of the inhibition of the mobility of Daphnia magna (Cladocera, Crustacea) - Acute toxicity test. ISO 6341. Geneve, Switzerland.

ISO (International Organization for Standardization) (2000): Water quality - Determination of the genotoxicity of water and waste water using the umu-test. ISO 13829. Geneve, Switzerland.

ISO (International Organization for Standardization) (2002f): Soil quality - Guidance on the ecotoxicological characterization of soils and soil materials. ISO 15799. Geneva, Switzerland.

ISO (International Organization for Standardization) (2004a): Water quality - Freshwater algal growth inhibition test with Desmodesmus subspicatus and Pseudokirchneriella subcapitata. ISO 8692. Geneve, Switzerland.

ISO (International Organization for Standardization) (2004b): Soil quality - Determination of the Effects of Pollutants on Soil Flora. Part II: Effects of Chemicals on the Emergence and Growth of Higher Plants. ISO 11269-2. Geneve, Switzerland.

ISO (International Organization for Standardization) (2007a): Water quality - Determination of the inhibitory effect on the light emission of Vibrio fischeri (Luminescent bacteria test). 11348-3. Geneva, Switzerland.

ISO (International Organization for Standardization) (2008a): Soil Quality - Avoidance test for evaluating the quality of soils and the toxicity of chemicals. Test with Earthworms (Eisenia fetida/andrei). ISO 17512-1. Geneve, Switzerland. 
ISO (International Organization for Standardization) (2008b): Soil quality - Guidance on the assessment of tests applied in the field of ecotoxicological characterization of soils and soil materials. ISO 17616. Geneve, Switzerland.

ISO (International Organization for Standardization) (2016a): Soil quality -- Contact test for solid samples using the dehydrogenase activity of Arthrobacter globiformis ISO 18187. Geneva, Switzerland.

Kostka-Rick, R. (2004): Ökotoxikologische Charakterisierung von Abfällen. LfU Baden-Württemberg, Karlsruhe. Ökologische Umweltbeobachtung (Karlsruhe). $108 \mathrm{~S}$.

LAGA (2004): Richtlinie für das Vorgehen bei physikalischen, chemischen und biologischen Untersuchungen in Zusammenhang mit der Verwertung/Beseitigung von Abfällen. Länderarbeitsgemeinschaft Abfall (Hrsg.). Berlin, Bielefeld München: Erich Schmidt Verlag.

LAGA (2012): Bund/Länder-Arbeitsgemeinschaft Abfall: LAGA-Methodensammlung Abfalluntersuchung. LAGA-Forum Abfalluntersuchung Version 2.0 Stand: 01. Oktober 2012

Marques, C.R., El-Azhari, N., Martin-Laurent, F., Pandard, P., Meline, C., Petre, A.L., Eckert, S., Zipperle, J., Váňa, M., Maly, S., Šindelářová, L., Amemori, A.S., Hofman, J., Kumar, A., Doan, H., McLaughlin, M., Richter, E. \& Römbke, J. (2018): A bacterium-based contact assay for evaluating the quality of solid samples - results from an international ring test. J. Hazardous Materials 352: 139-147.

Moser, H. (2008): Recommendations for the Ecotoxicological Characterization of Wastes. Federal Environmental Agency, Dessau, Germany. $25 \mathrm{pp}$.

Moser, H. and Römbke, J. (2009): Ecotoxicological characterisation of waste - Results and experiences of an European ring-test. Springer Ltd., New York. 308 pp.

Moser, H., Römbke, J., Donnevert, G. and Becker, R. (2011): Evaluation of biological methods for a future methodological implementation of the Hazard criterion H14 "ecotoxic" in the European waste list (2000/532/EC). Waste Manage. Res. 29: 180-187.
OECD (Organisation for Economic Co-operation and Development) (1992): Fish, Acute Toxicity Test. Guideline for Testing Chemicals No. 203. Paris, France.

Pandard, P., Devillers J., Charissou, A.M., Poulsen, V., Jourdain M.J., Férard, J-F., Grand, C. and Bispo, A. (2006): Selecting a Battery of Bioassays for Ecotoxicological Characterization of Wastes. Sci. Total Environ. 363: 114-125.

Pandard, P. and Römbke, J. (2013): Proposal for a "Harmonized" Strategy for the Assessment of the HP 14 Property. Integ. Envir. Assess. Manag. (IEAM) 9: 665-672.

Römbke, J., Moser, TH. and Moser, H. (2009): Ecotoxicological characterization of 12 incineration ashes (MWI) using 6 laboratory tests. Waste Manage. 29: 2475-2482.

Römbke, J., Jänsch, S. Meier, M., Hilbeck, A., Teichmann, H. and Tappeser, B. (2010): General recommendations for soil ecotoxicological tests suitable for the Environmental Risk Assessment (ERA) of Genetically Modified Plants (GMPs). Integr. Envir. Assess. Manag. (IEAM) 6: 287-300.

Römbke, J. and Ketelhut, R. (2014): Weiterentwicklung der UBA-Handlungsempfehlung zur ökotoxikologischen Charakterisierung von Abfällen. UBA-Texte 19/04, 170 pp.

Wahlström, M., Laine-Ylijoki, J., Wik, O., Oberender, A. and Hjelmar, O. (2016): Hazardous waste classification. Amendments to the European Waste Classification regulation - what do they mean and what are the consequences. Report TemaNord 519, $121 \mathrm{pp}$.

Weltens, R., Vanermen, R., Tirez, K., Robbens, J., Deprez, K. and Michiels, L. (2012): Screening tests for hazard classification of complex waste materials - Selection of methods. Waste Manage 32: 2208-2217.

Wilke, B-M., Riepert, F., Koch, C. and Kühne, T. (2007): Ecotoxicological characterization of hazardous waste. Ecotox. Envir. Safe 70: 283293. 